\title{
Cestrum nocturnum Flower Extracts Attenuate Proliferation and Induce Apoptosis in Malignant Cells through Inducing DNA Damage and Inhibiting Topoisomerase II Activity
}

\author{
Deng-Pan Wu, ${ }^{1,2}$ Tian-Yu Lin, ${ }^{1}$ Jin-Yan Lv, ${ }^{3}$ Wen-Ya Chen, ${ }^{4}$ Li-Ru Bai, ${ }^{1}$ Yan Zhou, ${ }^{1}$ \\ Jin-Lan Huang, ${ }^{1,2}$ and Zhen-Guo Zhong ${ }^{4}$ \\ ${ }^{1}$ Jiangsu Key Laboratory of New Drug Research and Clinical Pharmacy, Pharmacy School of Xuzhou Medical University, Xuzhou, \\ Jiangsu 221004, China \\ ${ }^{2}$ Department of Pharmacology, Pharmacy School of Xuzhou Medical University, Xuzhou, Jiangsu 221004, China \\ ${ }^{3}$ Faculty of Chinese Medicine Science, Guangxi University of Chinese Medicine, Nanning, \\ Guangxi Zhuang Autonomous Region 530200, China \\ ${ }^{4}$ Department of Science and Technology, Guangxi University of Chinese Medicine, Nanning, \\ Guangxi Zhuang Autonomous Region 530200, China
}

Correspondence should be addressed to Jin-Lan Huang; jinlanhuang@xzhmu.edu.cn and Zhen-Guo Zhong; gxtcmuzzg@163.com

Received 8 October 2016; Accepted 20 December 2016; Published 31 January 2017

Academic Editor: Ciara Hughes

Copyright (C) 2017 Deng-Pan Wu et al. This is an open access article distributed under the Creative Commons Attribution License, which permits unrestricted use, distribution, and reproduction in any medium, provided the original work is properly cited.

\begin{abstract}
Most of the existing chemotherapeutic drugs have plenty of side effects. Chinese herbal medicine has been used for pharmaceutical and dietary therapy for thousands of years with more effective and fewer side effects. Cestrum nocturnum (CN) has long been used to treat digestive diseases for centuries in China. Our previous study first proved that the n-butanol part isolated from the flowers of $\mathrm{CN}$ produced an inhibitory effect on the proliferation of malignant cells. However, the fractions responsible for the antiproliferation effect of $\mathrm{n}$-butanol part from $\mathrm{CN}$ flowers and related mechanisms remain unknown. Thus, in this study, we extracted fractions $\mathrm{C} 4$ and $\mathrm{C} 5$ from n-butanol part of $\mathrm{CN}$ flowers and investigated their immune toxicity and antitumor activities. It was found that fractions $\mathrm{C} 4$ and $\mathrm{C} 5$ exhibited great cytotoxicity to cancer cell lines but had low immune toxicity towards $\mathrm{T}$ and $\mathrm{B}$ lymphocytes in vitro. The tested fractions also attenuated proliferation and induced apoptosis at $G_{0} / G_{1}$ and $G_{2} / M$ phases in Bel-7404 cells through inducing DNA damage and inhibiting topoisomerase II relaxation activity. These results suggest that fractions C4 and C5 may represent important sources of potential antitumor agents due to their pronounced antitumor effects and low immune toxicity.
\end{abstract}

\section{Introduction}

Malignancy tumor has been ranked the fourth cause of death worldwide [1] and is responsible for about 1600 deaths everyday [2]. Although the methods of cancer diagnosis and therapy have made a rapid progress recently, the efficacy of cancer treatments has not been improved significantly yet. Currently, the prevailing approaches to treating malignant tumor include surgery and chemotherapy. However, most of chemotherapeutic drugs present plenty of side effects. Therefore, searching for safe and effective antitumor agents is the aim of current anticancer research.
Cestrum nocturnum (CN), a plant that belongs to the genus Cestrum nocturnum Linn., family Solanaceae, is widely distributed in Fujian, Guangdong, and Yunnan provinces as well as Guangxi Zhuang Autonomous Region, China. CN has long been used in traditional Chinese medicine (TCM) to treat digestive diseases for centuries [3]. Numerous studies have identified that $\mathrm{CN}$ has a great deal of pharmacological actions, including analgesic action, central inhibitory action, and antidiabetic activity [4-6]. Our previous study first proved that the n-butanol part isolated from the flowers of $\mathrm{CN}$ produced an inhibitory effect on the proliferation of human hepatocellular carcinoma Bel-7404, human gastric 
carcinoma SGC-7901, and cervical cancer HeLa cells in a dose-dependent manner [7]. However, the fractions responsible for the antiproliferation effect of $n$-butanol part from $\mathrm{CN}$ flowers and related mechanisms remain unknown.

Thus, this study was designed to evaluate the cytotoxicity of the fractions isolated from n-butanol part of $\mathrm{CN}$ flowers towards selected human malignant cell lines to determine the active fractions, elucidate the possible mechanisms of the cytotoxic effects of the tested fractions, and measure the immune toxicity of the fractions in vitro, so as to provide evidence for these fractions as potential antitumor agents.

\section{Materials and Methods}

2.1. Chemicals. The flowers of $\mathrm{CN}$ were collected in Guangxi Zhuang Autonomous Region, China, and verified by Professor Liu Shouyang from Guangxi University of Chinese Medicine. The voucher specimen (collection number: PE01621610) is deposited in Chinese Virtual Herbarium in Kunming, Yunnan province. Air-dried and powdered CN flowers $(1.948 \mathrm{~kg}$ ) were conducted with $95 \%$ and $50 \%$ ethanol (each $4000 \mathrm{~mL}$ ) by percolating at room temperature overnight to give total ethanol extracts $(424 \mathrm{~g})$. The extracts were then mixed with silica gel thoroughly and sequentially partitioned with petroleum ether $(2000 \mathrm{~mL})$, acetic ether $(2000 \mathrm{~mL})$, water-saturated $\mathrm{n}$-butanol $(2000 \mathrm{~mL})$, and $95 \%$ ethanol $(2000 \mathrm{~mL})$ to obtain four different parts. n-Butanol part $(100 \mathrm{~g})$ was subjected to macroporous resin column, eluting with water $(1000 \mathrm{~mL}), 20 \%$ ethanol $(1000 \mathrm{~mL}), 50 \%$ ethanol $(1000 \mathrm{~mL}), 70 \%$ ethanol $(1000 \mathrm{~mL})$, and $95 \%$ ethanol $(1000 \mathrm{~mL})$ to give fraction B1 $(20 \mathrm{~g}), \mathrm{B} 2(14 \mathrm{~g}), \mathrm{B} 3(29.5 \mathrm{~g})$, B4 $(6 \mathrm{~g})$, and B5 (1g), respectively. Using silica gel column chromatography, fraction B4 was partitioned with a gradient $\mathrm{CHCl}_{3}: \mathrm{CH}_{3} \mathrm{OH}(30: 1$ to $1: 1$, each $1000 \mathrm{~mL})$ and $\mathrm{CHCl}_{3}: \mathrm{CH}_{3} \mathrm{OH}$ : water $(65: 35: 10,1000 \mathrm{~mL})$ to give fraction $\mathrm{Cl} \sim \mathrm{C} 10$, respectively. The qualitative chemical profile of fractions C4 and C5 was analyzed by high-performance liquid chromatography (HPLC). The chemical formulas of compounds in fractions C4 and C5 were analyzed by single mass. In addition, the active ingredients in fractions $\mathrm{C} 4$ and C5 were analyzed by phytochemical analysis. HPLC, single mass, and phytochemical analysis were performed as described in the Chinese Pharmacopoeia (sixth edition).

2.2. Reagents. Wright's stain was obtained from SSS Reagent Co., Ltd., Shanghai, China. Giemsa's stain was from Chemical Reagent Factory, Shanghai, China. Agarose was from BioScience and Technology Limited Company, Shanghai, China. RNAse A was purchased from Shanghai Bio-Technology Limited, Shanghai, China. Low melting point agarose was from Dahui Bio-Technology Limited, Guangzhou, China. Propidium iodide (PI) and Hoechst 33342 were obtained from KeyGEN Bio-Technology Limited Company, Nanjing, China. pBR 322 DNA plasmid was from Takara BioTechnology Limited Company, Dalian, China. Topoisomerase II $\alpha$ was purchased from KeyGEN Bio-Technology Limited Company, Nanjing, China. All other reagents were from Sigma-Aldrich unless stated otherwise.
2.3. Cell Culture and Treatment. Single T and B cell suspensions were isolated from the spleens of healthy Kunming mice and cultured in RPMI-1640 (Invitrogen, America) containing $10 \%$ fetal bovine serum (FBS, Hyclone, America). Human nasopharyngeal carcinoma CNE-2Z, human hepatoma Bel7404, and human cervical cancer HeLa cell lines obtained from Shanghai Biological Institute were cultured in RPMI1640 (Invitrogen, America) containing 10\% FBS (Hyclone, America) in $5 \% \mathrm{CO}_{2}$ at $37^{\circ} \mathrm{C}$. The cell lines were divided into a control group and experimental groups treated with different concentrations of extracts from $\mathrm{CN}$ flowers.

\subsection{Detection of Cytotoxicity by Methyl Thiazolyl Tetrazolium} (MTT) Assay. CNE-2Z, Bel-7404, and HeLa cells were seeded to 96 -well plates for $24 \mathrm{~h}$. The cells of experimental groups were treated with fractions $\mathrm{B} 1 \sim \mathrm{B} 5, \mathrm{C} 1 \sim \mathrm{C} 10$, or 5fluorouracil (5-Fu, positive control) at the concentrations of $5 \mu \mathrm{g} / \mathrm{mL}, 10 \mu \mathrm{g} / \mathrm{mL}, 20 \mu \mathrm{g} / \mathrm{mL}, 40 \mu \mathrm{g} / \mathrm{mL}$, and $80 \mu \mathrm{g} / \mathrm{mL}$ for $72 \mathrm{~h}$, respectively. $0.2 \mathrm{mg} / \mathrm{mL}$ MTT solution was then added to incubate the cells for $4 \mathrm{~h}$ followed by removing the supernatant and adding $100 \mu \mathrm{L}$ of DMSO. Absorbance at $450 \mathrm{~nm}$ wavelength $\left(A_{450}\right)$ was detected using an enzymelabeling instrument (Sunrise, Biocell). Inhibition rate (IR) $=$ ( 1 - average $A_{450}$ of the experimental group/the average $A_{450}$ of the control group) $\times 100 \%$.

\subsection{Detection of Immune Toxicity by Cell Counting Kit-8} (CCK-8) Assay. $2 \times 10^{6}$ cells $/ \mathrm{mL}$ single $\mathrm{T}$ and $\mathrm{B}$ cell suspensions were seeded into 96 -well plates (100 $\mu \mathrm{L} /$ well). After exposure to $5 \mu \mathrm{g} / \mathrm{mL}$ Con A (Solarbio, China) and $10 \mu \mathrm{g} / \mathrm{mL}$ LPS (Solarbio, China), T and B cells were treated with 5, 10, 20,40 , and $80 \mu \mathrm{g} / \mathrm{mL}$ fraction $\mathrm{C} 4$ or $\mathrm{C} 5$ for $72 \mathrm{~h}$, respectively. $10 \mu \mathrm{L}$ of CCK-8 (Dojindo, Japan) solution was added to incubate the cells for $1 \mathrm{~h}$. Absorbance at $450 \mathrm{~nm}$ wavelength $\left(A_{450}\right)$ was detected by an enzyme-labeling instrument (Sunrise, Biocell). The inhibition rate (IR) $=\left(1-\right.$ average $A_{450}$ of the experimental group/the average $A_{450}$ of the control group) $\times$ $100 \%$.

2.6. Detection of Proliferation by Colony Forming Assay. 200 cells/mL Bel-7404 cells were seed into 24-well plates overnight. Cells were treated with $10 \mu \mathrm{g} / \mathrm{mL}$ fraction $\mathrm{C} 4, \mathrm{C} 5$, or 5-Fu (positive control). The cells were incubated for 7 days. During this period, each individual surviving cell would proliferate and form colonies. On Day 7, after the supernatant was removed, the colonies were stained with Wright's stain for $5 \mathrm{~min}$ followed by Giemsa's stain for $10 \mathrm{~min}$. The colonies were then washed and dried. The colonies with $>50$ cells/colony were counted. The colony formation rate $=$ the number of colony/the number of cells seeded into plate $\times 100 \%$.

2.7. Detection of Cell Cycle by Flow Cytometry (FCM). $10^{5}$ cells $/ \mathrm{mL}$ Bel-7404 cells were seeded into a 6-well plate for $24 \mathrm{~h}$, and then the cells were treated with or without $10 \mu \mathrm{g} / \mathrm{mL}$ fraction $\mathrm{C} 4$ or $\mathrm{C} 5$ for $72 \mathrm{~h}$. The cells were collected and washed with PBS twice and fixed with cold 70\% alcohol at $4^{\circ} \mathrm{C}$ for $24 \mathrm{~h}$. After the alcohol was removed, the cells were then washed with cold PBS twice, exposed to $50 \mu \mathrm{g} / \mathrm{mL}$ Rnase $\mathrm{A}$ at $37^{\circ} \mathrm{C}$ for $1 \mathrm{~h}$, and stained with $10 \mu \mathrm{g} / \mathrm{mL}$ PI and $2 \mathrm{mM}$ 
Hoechst33342. Cell cycle and apoptosis were detected using FCM (BD, America).

2.8. Detection of DNA Damage by Alkaline Comet Assay. The alkaline comet assay was performed and modified following Singh protocol [8]. $10^{6}$ cells/mL Bel-7404 cells were seeded into a 6-well plate for $24 \mathrm{~h}$ followed by treatments with or without $40 \mu \mathrm{g} / \mathrm{mL}$ fractions $\mathrm{C} 4$ and $\mathrm{C} 5$ for $72 \mathrm{~h}$. The medium was removed and the cells were washed with ice cold PBS and trypsinized. $10^{6}$ cells/mL of cell suspension in PBS was mixed with $1 \%$ low melting point agarose $(1: 3, \mathrm{v} / \mathrm{v})$ at $37^{\circ} \mathrm{C}$, and then the suspension was pipetted onto slides precoated with normal melting point agarose. Slides with embedded cells in agarose were allowed to solidify at $4^{\circ} \mathrm{C}$ for $10 \mathrm{~min}$. The slides were then placed for $40 \mathrm{~min}$ in a freshly prepared lysis buffer (2.5 M NaC1, 100 mM EDTA, 10 mM Tris, 1\% Triton X-100, and $10 \%$ DMSO, pH 10). After lysis, the slides were placed in a horizontal electrophoresis chamber and incubated for $30 \mathrm{~min}$ at $4^{\circ} \mathrm{C}$ in an electrophoresis buffer $(300 \mathrm{mM} \mathrm{NaOH}$ and $1 \mathrm{mM}$ $\mathrm{Na}_{2}$ EDTA, pH 13) for alkali DNA unwinding. Electrophoresis was performed in the same buffer for $40 \mathrm{~min}$ at $20 \mathrm{~V}$ and $240 \mathrm{~mA}$ at $4^{\circ} \mathrm{C}$. After electrophoresis, the slides were rinsed three times with $0.4 \mathrm{M}$ Tris- $\mathrm{HCl}(\mathrm{pH} 7.5)$ for $5 \mathrm{~min}$ and then stained with ethidium bromide (EB) (Beyotime, China). The comets were observed by fluorescent microscope (Nikon, Japan). Fifty cells were randomly selected per slide and the content of head and tail DNA in the comet was measured by comet assay software project (CASP). The percentages of DNA in the comet head (headDNA\%) and tail (tailDNA\%) were considered as parameters of the content of head and tail DNA, respectively.

2.9. Cleavage Assay of Topoisomerase II. This assay was performed according to Janočková et al. and Ketron et al. with modification $[9,10]$. In the assay, plasmid PBR322 DNA containing supercoiled and linear DNA was used as the cleavage substrate of topoisomerase II. In brief, the reaction system was a $20 \mu \mathrm{L}$ reaction mixture containing $5 \mu \mathrm{L}$ reaction buffer (50 mM Tris- $\mathrm{HCl}, \mathrm{pH}$ 7.5, $85 \mathrm{mM} \mathrm{KCl,} 10 \mathrm{mM} \mathrm{MgCl}$, $5 \mathrm{mM}$ DTT, $30 \mathrm{~g} / \mathrm{mL}$ BSA, $5 \mathrm{mM}$ EDTA, and $1 \mathrm{mM}$ ATP), $2 \mu \mathrm{L}$ plasmid PBR322DNA (final concentration: $10 \mu \mathrm{g} / \mathrm{mL}$ ), $10 \mu \mathrm{L}$ topoisomerase II $\alpha$ and $3 \mu \mathrm{L}$ fraction $\mathrm{C} 4$ (final concentration: 10, 20, or $40 \mu \mathrm{g} / \mathrm{mL}$ ), or C5 (final concentration: 10, 20 or $40 \mu \mathrm{g} / \mathrm{mL}$ ) or topoisomerase II inhibitor etoposide (Selleck Chemicals, America, final concentration: $100 \mu \mathrm{M}$, positive control). The reactions were carried out for $30 \mathrm{~min}$ at $37^{\circ} \mathrm{C}$ and stopped by adding $10 \mu \mathrm{L} \mathrm{10 \%} \mathrm{SDS.} \mathrm{Samples} \mathrm{were} \mathrm{digested}$ by $10 \mathrm{mg} / \mathrm{mL}$ proteinase $\mathrm{K}$ (Beyotime, China) at $37^{\circ} \mathrm{C}$ for $30 \mathrm{~min}$. Gel electrophoresis was performed at $50 \mathrm{~V} / \mathrm{cm}$ for $1.5 \mathrm{~h}$ in a $0.5 \mathrm{x}$ TBE buffer containing $8.9 \times 10^{-2} \mathrm{M}$ Tris, $8.9 \times 10^{-2} \mathrm{M} \mathrm{H}_{3} \mathrm{BO}_{3}$, and $2.0 \times 10^{-3} \mathrm{M}$ EDTA on $0.8 \%$ agarose gel which was stained with $1 \mathrm{mg} / \mathrm{mL}$ EB. DNA bands were visualized using ultraviolet (UV) light (UVP, America). DNA cleavage was monitored by the conversion of supercoiled plasmid DNA to linear molecules. The intensity of linear DNA band in each lane was measured using imageJ software.
TABLE 1: The concentrations of the $\mathrm{CN}$ flower fractions, which induced $50 \%$ decrease in malignant cells survival, according to MTT assay.

\begin{tabular}{lccc}
\hline Fractions & \multicolumn{3}{c}{$\mathrm{IC}_{50}(\mu \mathrm{g} / \mathrm{mL})$} \\
Bel-7404 & HeLa \\
\hline B1 & 411.71 & 440.11 & 845.9 \\
B2 & 213.51 & 281.01 & 933.58 \\
B3 & 34.42 & 37.23 & 73.87 \\
B4 & 17.50 & 11.08 & 23.59 \\
B5 & 202.1 & 201.13 & 181.70 \\
C1 & 130.33 & 75.9 & 150.78 \\
C2 & 162.53 & 109.49 & 909.41 \\
C3 & 403.13 & 205.30 & 550.77 \\
C4 & 19.78 & 18.71 & 19.21 \\
C5 & 22.98 & 19.62 & 19.70 \\
C6 & 211.10 & 360.32 & 144.68 \\
C7 & 588.06 & 222.92 & 211.01 \\
C8 & 387.63 & 113.80 & 335.91 \\
C9 & 245.55 & 109.38 & 199.93 \\
C10 & 272.11 & 201.4 & 452.3 \\
$5-F u$ & 16.43 & 2.32 & 8.96 \\
\hline
\end{tabular}

The cells were exposed to the agents for $72 \mathrm{~h}$.

2.10. Statistical Analysis. Experimental data in each group were presented as mean \pm SD. Analysis of variance was performed with SPSS software for windows 11.0. $P<0.05$ was considered statistically significant.

\section{Results}

3.1. In Vitro Cytotoxic Activity. In order to measure the cytotoxicity of the fractions isolated from the n-butanol part of CN flowers, we first treated CNE-2Z, Bel-7404, and HeLa cells with different concentrations of fractions B1, B2, B3, B4, or B5 isolated from the n-butanol part of $\mathrm{CN}$ flowers for $72 \mathrm{~h}$. MTT assay was used to measure the cytotoxicity of the fractions to these malignant cells. All fractions investigated exerted cytotoxic effects on the malignant cells in a dose-dependent manner. The increase in inhibitory efficacy induced by the five fractions of $\mathrm{CN}$ is shown in Figures 1(a), 1(b), and 1(c). It should be noted that fraction B4 exhibited the highest cytotoxic effects against the target malignant cells as shown by the corresponding inhibitory concentration $50 \%\left(\mathrm{IC}_{50}\right)$ in Table 1.

For further investigating effective antineoplastic fractions of CN flowers, fraction B4 was partitioned with a gradient $\mathrm{CHCl}_{3}: \mathrm{CH}_{3} \mathrm{OH}$ using silica gel column chromatography and ten fractions (from $\mathrm{Cl}$ to $\mathrm{C} 10$ ) were obtained. MTT assay showed that fractions C4 and C5 exited the greatest cytotoxicity to malignant cells as shown by the inhibition rate and the corresponding $\mathrm{IC}_{50}$ of target cells in Figures $1(\mathrm{~d}), 1(\mathrm{e})$, and 1 (f) and Table 1 , respectively. 

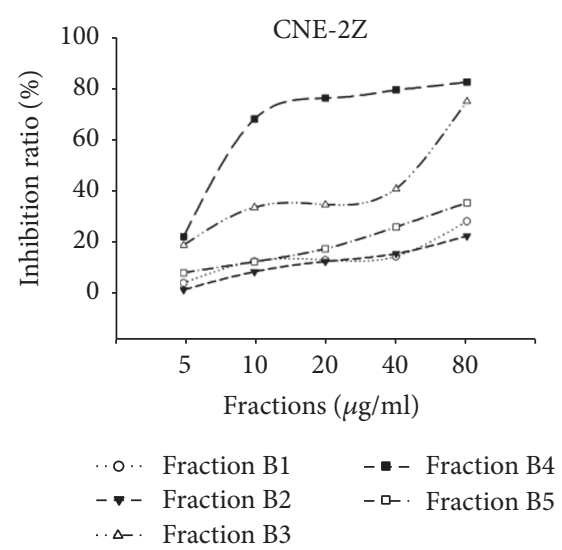

(a)
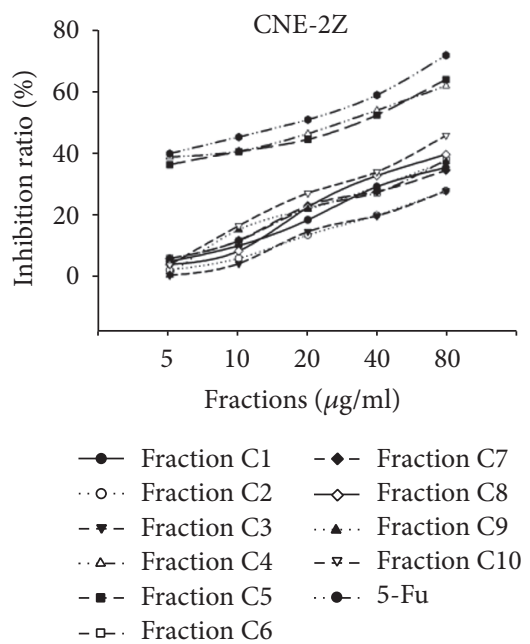

(d)

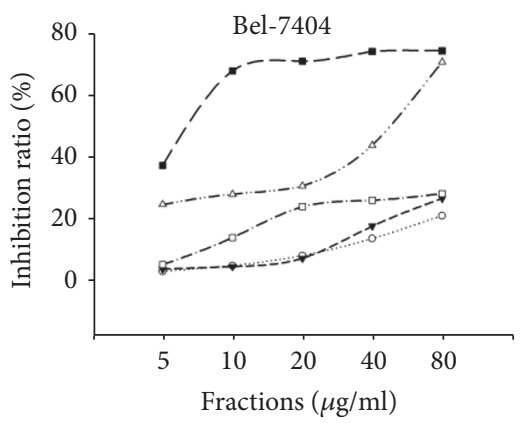

... Fraction B1 - - Fraction B4

- - Fraction B2 - - . Fraction B5

$\triangle$. Fraction B3

(b)
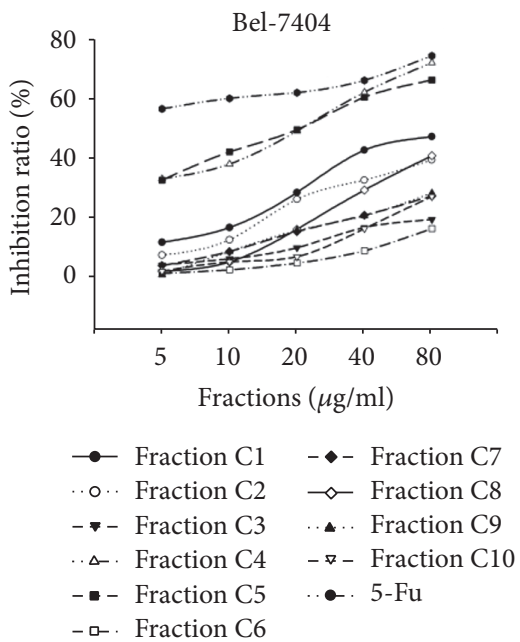

(e)
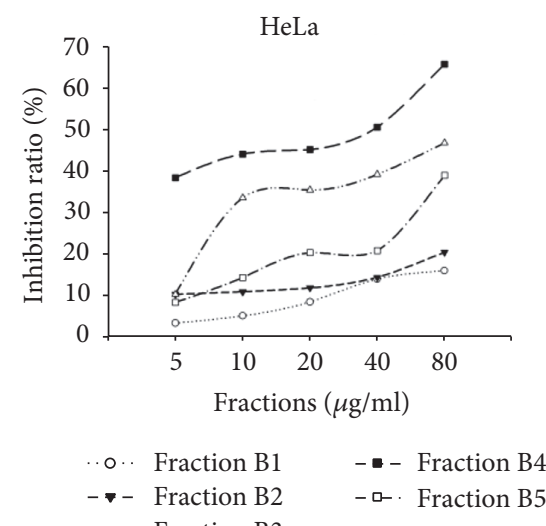

$\sim \Delta$. Fraction B3

(c)
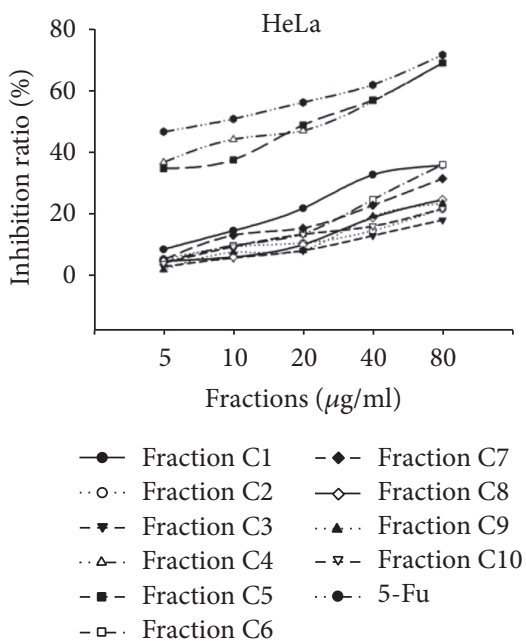

(f)

FIgURE 1: In vitro cytotoxicity of the extracts from CN flowers. MTT assay was used to estimate the cytotoxicity of the extracts to CNE-2Z, Bel-7404, and HeLa cells. Representative graphs are shown.

3.2. Phytochemical Analysis, HPLC, and Single Mass Analysis of Fractions C4 and C5 of CN Flowers. According to phytochemical analysis, steroidal saponins were found in fractions C4 and C5 since the appearance of green to pink color after the samples were treated with chloroform, acetic anhydride, and a series of concentrated $\mathrm{HCl}$, and frothing bubbles were observed after vigorous shaking using diluted samples. HPLC and single mass analysis were adopted to identify the chemical profiles and formulas of compounds in fractions C4 and C5. Results showed that there were 2 main peaks in fractions $\mathrm{C} 4$ and $\mathrm{C} 5$ (Figure 2), and the chemical formulas of compounds were $\mathrm{C}_{56} \mathrm{H}_{90} \mathrm{O}_{28}(5.14 \mathrm{~min})$ and $\mathrm{C}_{63} \mathrm{H}_{102} \mathrm{O}_{30}$ (5.92 min) in fraction $\mathrm{C} 4$ and $\mathrm{C}_{56} \mathrm{H}_{90} \mathrm{O}_{28}(5.14 \mathrm{~min})$ and $\mathrm{C}_{50} \mathrm{H}_{80} \mathrm{O}_{23}(5.40 \mathrm{~min}$ ) in fraction C5 (Figure 2).

\subsection{Effects of Fractions $C 4$ and $C 5$ on Immune Toxicity. After} treatment with different concentrations of fraction $\mathrm{C} 4$ or $\mathrm{C} 5$ for $72 \mathrm{~h}, \mathrm{CCK}-8$ assay was used to measure the proliferation of $\mathrm{T}$ and $\mathrm{B}$ cells to assess the immune toxicity of the fractions. The $\mathrm{IC}_{50}$ values of fraction $\mathrm{C} 4$ for $\mathrm{T}$ and $\mathrm{B}$ cells reached to $414.77 \mu \mathrm{g} / \mathrm{mL}$ and $559.91 \mu \mathrm{g} / \mathrm{mL}$, respectively, and the $\mathrm{IC}_{50}$ values of fraction C5 for T and B cells were $543.31 \mu \mathrm{g} / \mathrm{mL}$ and $244.41 \mu \mathrm{g} / \mathrm{mL}$, respectively, indicating that fractions $\mathrm{C} 4$ and C5 have low immune toxicity in vitro.

3.4. Effects of Fractions $C 4$ and $C 5$ on Colony Formation. For further confirming the antineoplastic effects of fractions $\mathrm{C} 4$ and $\mathrm{C} 5$, colony forming assay was performed to determine the proliferation of Bel-7404 cells after exposure to $10 \mu \mathrm{g} / \mathrm{mL}$ of fraction $\mathrm{C} 4, \mathrm{C} 5$, or 5-fluorouracil (5-Fu) for 7 days. Results revealed that the colony formation rate of the cells treated with fraction C4 or C5 was remarkably decreased compared with the control cells (Figures 3(a) and 3(b)), suggesting that the proliferation of Bel-7404 cells is attenuated by fractions C4 and C5.

3.5. Analysis of Changes in Cell Cycle Phase Distribution. The effects of fractions C4 and C5 on Bel-7404 apoptosis and cell cycle distribution were measured by flow cytometry. As shown in Figures 3(c) and 3(d), treatment with $10 \mu \mathrm{g} / \mathrm{mL}$ fraction $\mathrm{C} 4$ or $\mathrm{C} 5$ for $72 \mathrm{~h}$ resulted in an increase in the number of the cells at the $G_{0} / G_{1}$ and $G_{2} / M$ phases whereas a 


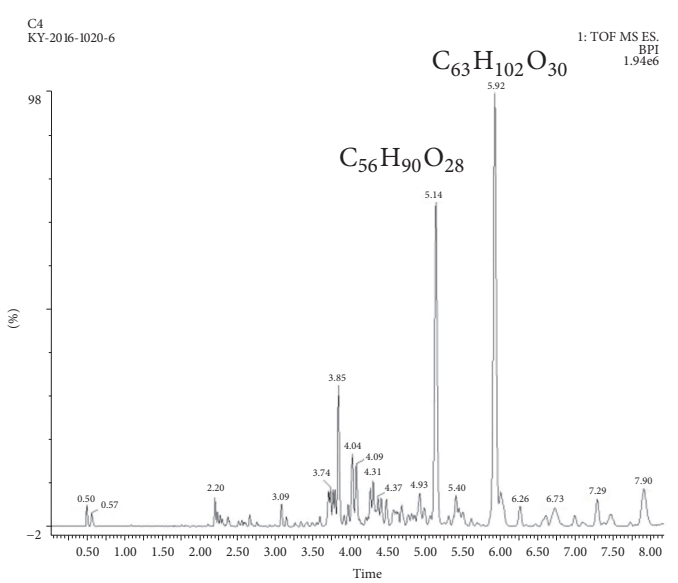

(a)

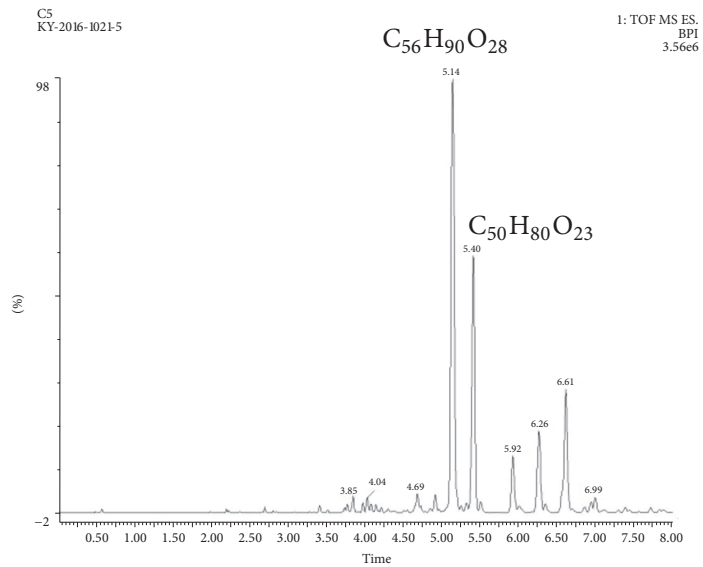

(b)

FIGURE 2: HPLC chromatograms of fractions C4 and C5. The chemical formulas of the main compounds in fractions C4 and C5 were analyzed using single mass analysis.

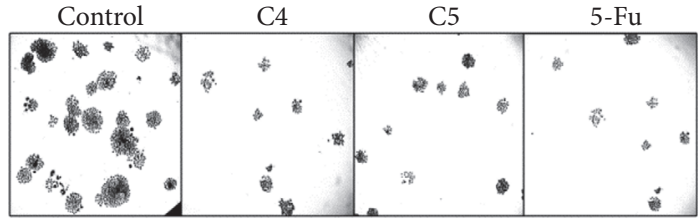

(a)

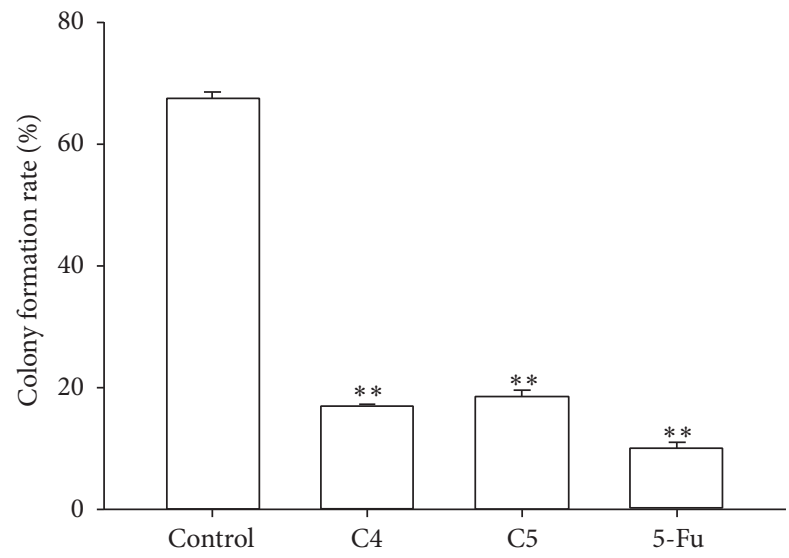

(b)

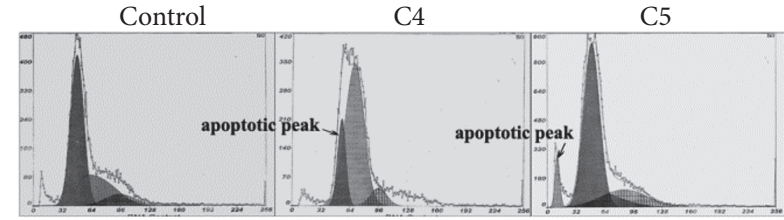

(c)

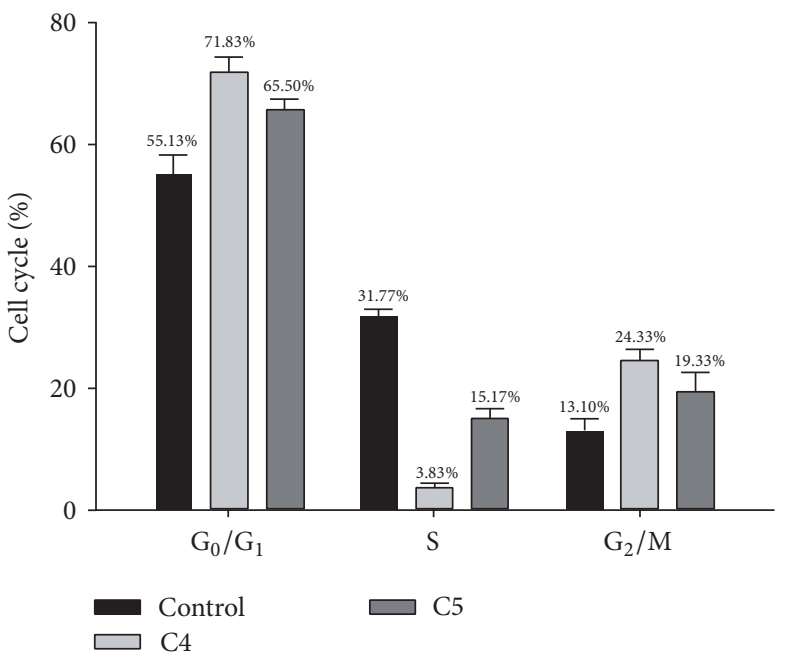

(d)

Figure 3: (a) and (b) Effects of fractions C4 and C5 on the colony formation of Bel-7404 cells. After the cells were treated with fraction C4, $\mathrm{C} 5$, or $5-\mathrm{Fu}$, the colonies ( $>50$ cells/colony) were counted and the colony formation rate of each group was calculated. The data in different groups were expressed as the mean \pm SD from 3 experiments. Statistical difference between groups was assessed by $t$-test using SPSS 20.0 . ${ }^{* *} P<0.01$ versus the control group. (c) and (d) Flow cytometric analysis of the cell cycle distribution of Bel-7404 cells treated with fraction $\mathrm{C} 4$ or $\mathrm{C} 5$.

decreased number of the cells at the $S$ phases compared with the control cells and an apoptotic peak were observed after treatment with fraction $\mathrm{C} 4$ or $\mathrm{C} 5$. These results indicate that fractions $C 4$ and $C 5$ arrest the cells at the $G_{0} / G_{1}$ and $G_{2} / M$ phases and cause apoptosis.
3.6. Detection of DNA Damage Using Alkaline Comet Assay. Comet assay is generally used to measure single and doublestrand breaks, DNA repair, alkali labile sites, and DNAprotein/DNA-DNA/DNA-agent cross linkage [11]. The principle of the assay depends on strand breakage of the supercoiled 


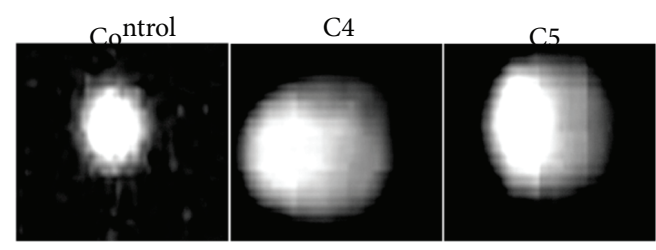

(a)

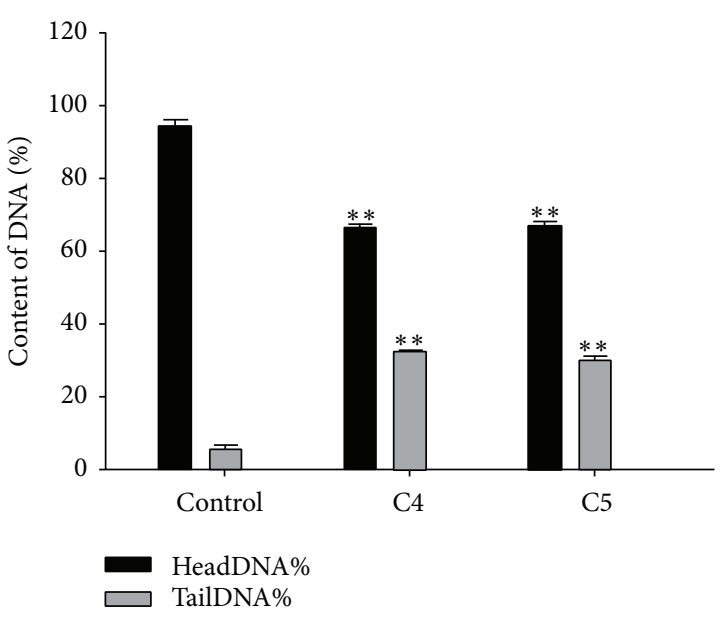

(b)

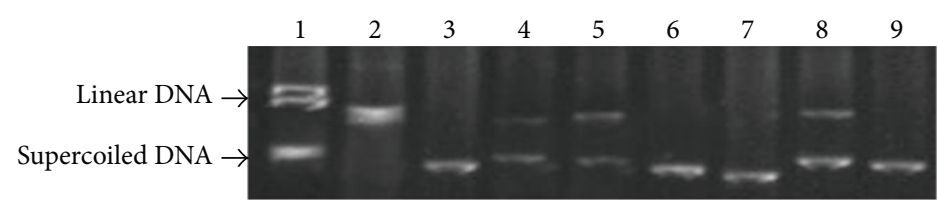

(c)

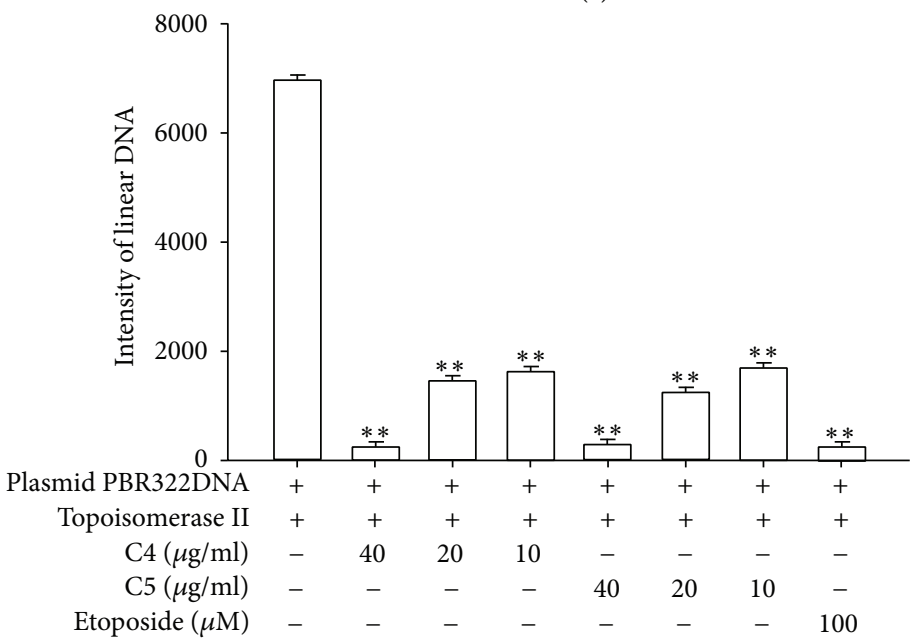

(d)

Figure 4: (a) and (b) DNA damage induced by fractions C4 and C5 in Bel-7404 cells measured by comet assay. Fifty cells were randomly selected per slide and the contents of head and tail DNA in the comet were measured by comet assay software project (CASP). The percentages of DNA in the comet head (headDNA\%) and tail (tailDNA\%) were considered as parameters of the content of head and tail DNA, respectively. The data in different groups were expressed as the mean \pm SD from 3 experiments. Statistical difference between groups was assessed by $t$-test using SPSS 20.0. ${ }^{* *} P<0.01$ versus the control group. (c) and (d) Effects of fractions C4 and C5 on topoisomerase II activity. Topoisomerase II activity was measured by plasmid DNA cleavage assay. DNA bands were visualized using UV light and the intensity of linear DNA band in each lane was measured using imageJ software. Lane 1: plasmid PBR322DNA. Lane 2: control, topoisomerase II + plasmid PBR322DNA. Lanes 3, 4, and 5: 40, 20, and $10 \mu \mathrm{g} / \mathrm{mL}$ fraction C4 + plasmid PBR322DNA, respectively. Lanes 6, 7, and 8: 40, 20, and 10 $\mu \mathrm{g} / \mathrm{mL}$ fraction C5 + plasmid PBR322DNA, respectively. Lane 9: $100 \mu \mathrm{M}$ etoposide + plasmid PBR322DNA. The data in different groups were expressed as the mean \pm SD from 3 experiments. Statistical difference between groups was assessed by $t$-test using SPSS $20.0 .{ }^{* *} P<0.01$ versus the control group.

double helical DNA, resulting in the reduction in the size of large molecules. Comets form when these broken ends of the negatively charged DNA molecule can migrate freely towards the anode in the electric field [12]. If DNA breakage were induced, the percentage of DNA in the comet head would decline; in contrast, the percentage of DNA in the comet tail would increase. In the present study, DNA damage of Bel7404 cells was assessed using comet assay after these cells were treated with $40 \mu \mathrm{g} / \mathrm{mL}$ fraction $\mathrm{C} 4$ or C5 for $72 \mathrm{~h}$. As shown in Figures 4(a) and 4(b), the comets of fraction C4 or C5 treated cells were clearly visible under the microscope. However, no comet formation was observed within untreated cells. In addition, the percentage of head DNA in fraction C4 or C5 treated cells was remarkably lower than the control group. In contrast, the percentage of tail DNA that revealed the actual DNA damage, in the cells which are exposure to the studied fractions, was significantly increased compared to the control group. Specifically, the percentages of tail DNA in fraction C4 and C5 treated cells were approximately 33\% and $30 \%$, respectively, whereas the percentage of tail DNA in control group was $6 \%$, so fractions $\mathrm{C} 4$ and $\mathrm{C} 5$ increased the contents of tail DNA by a factor of approximately 5 . These results indicate that fractions $\mathrm{C} 4$ and $\mathrm{C} 5$ have abilities to induce DNA damage.

\subsection{Effects of Fractions C4 and C5 on DNA Relaxation} Activity of Topoisomerase II. It has been established that topoisomerase II relaxes the helical supercoiling of DNA that is generated during replication, chromatin remodeling, and transcription, leading to the conversion of supercoiled DNA to linear molecules [13]. In order to investigate the effects of fractions $\mathrm{C} 4$ and $\mathrm{C} 5$ on topoisomerase II relaxation activity, plasmid DNA cleavage assay was performed in the study. This assay is a specific reaction of topoisomerase II involving the simultaneous cleavage of supercoiled DNA. If the relaxation activity of topoisomerase II were allowed to continue unimpeded, supercoiled DNA would be cleaved by topoisomerase II and replaced by linear forms of DNA. On the contrary, if the enzymatic activity of topoisomerases II were suppressed, these linear DNA bands would not be detected. As illustrated in Figures 4(c) and 4(d), fractions $\mathrm{C} 4$ and C5 could reduce the intensity of linear DNA band 
in a dose-dependent manner, suggesting that fractions $\mathrm{C} 4$ and $\mathrm{C} 5$ have abilities to inhibit the DNA relaxation activity of topoisomerases II. Fractions $\mathrm{C} 4$ and $\mathrm{C} 5$ at $40 \mu \mathrm{g} / \mathrm{mL}$ could completely inhibit the relaxation activity of topoisomerases II in a way similar to that of a known topoisomerase II inhibitor, etoposide $(100 \mu \mathrm{M})$ since linear DNA bands in these groups were rarely detected (Figures $4(\mathrm{c})$ and $4(\mathrm{~d})$ ).

\section{Discussion}

Chemotherapy, radiation, and surgery are the most paramount strategies used for the treatment of malignant tumors. However, these treatments exert various side effects. Chinese herbal medicine has been used for pharmaceutical and dietary therapy for thousands of years with more effective and fewer side effects. Therefore, developing safe and highly effective anticancer herbal agents have gradually become a hot area. In this study, we prepared different fractions from the n-butanol extract of $\mathrm{CN}$ flowers and measured their cytotoxicity to malignant cells using MTT assay. It was found that fractions $\mathrm{C} 4$ and $\mathrm{C} 5$ isolated from the n-butanol fraction of $\mathrm{CN}$ flowers had pronounced cytotoxic activities against CNE-2Z, Bel-7404, and HeLa cells (Figures $1(\mathrm{~d}), 1(\mathrm{e})$, and $1(\mathrm{f}))$. The results of phytochemical analysis showed that the tested fractions were mainly composed of steroidal saponins. The findings of HPLC and single mass analysis revealed that the compounds, with the chemical formulas of $\mathrm{C}_{56} \mathrm{H}_{90} \mathrm{O}_{28}$ (5.14 min), $\mathrm{C}_{63} \mathrm{H}_{102} \mathrm{O}_{30}$ (5.92 min), and $\mathrm{C}_{50} \mathrm{H}_{80} \mathrm{O}_{23}(5.40 \mathrm{~min})$, accounted for a large proportion of fractions C4 and C5 (Figure 2), suggesting that these compounds may belong to steroidal saponins. Since most steroidal saponins were reported to produce great cytotoxicity towards cancer cells [14], the indicated compounds may exert antineoplastic activity and make contribution to the cytotoxicity of the tested fractions to malignant cells. It would be interesting to identify the chemical structures of these compounds and investigate their antitumor activities in the future study.

Increasing the antitumor activity of existing anticancer drugs, rather than enhancement of its toxicity, is the aim of current anticancer research. In our study, CCK-8 assay was used to investigate the immune toxicity of fractions $\mathrm{C} 4$ and $\mathrm{C} 5$ towards $\mathrm{T}$ and $\mathrm{B}$ lymphocytes. The results showed that the IC50 values of fractions $\mathrm{C} 4$ and $\mathrm{C} 5$ for T cells reached to $414.77 \mu \mathrm{g} / \mathrm{mL}$ and $543.31 \mu \mathrm{g} / \mathrm{mL}$, respectively, while the IC50 values of fractions C4 and C5 for B cells were $559.91 \mu \mathrm{g} / \mathrm{mL}$ and $244.41 \mu \mathrm{g} / \mathrm{mL}$, respectively, indicating that fractions C4 and $\mathrm{C} 5$ have mild immune toxicity in vitro.

Evaluation of the proliferation of cells is a noteworthy step since most of anticancer drugs are less cytocidal to quiescent cells than to actively proliferating cells [15]. In order to further assess the antitumor activities of fractions $\mathrm{C} 4$ and $\mathrm{C} 5$, colony forming assay was performed to determine the role of the tested fractions in the proliferation of Bel-7404 cells. The results revealed that treatment with fractions $\mathrm{C} 4$ and $\mathrm{C} 5$ exhibited an inhibitory effect of colony formation (Figures 3(a) and 3(b)), indicating that fractions C4 and C5 possess the abilities to attenuate the proliferation of Bel-7404 cells.
Apoptosis is the physiological process that contributes to elimination of unnecessary and unwanted cells to maintain the healthy balance between cell survival and cell death [16]. Abnormal apoptosis plays important roles in tumorigenesis and tumor progression. Inducing tumor cell apoptosis to annihilate tumor cells is one of the mechanisms of antineoplastics. In the present study, an apoptotic peak was observed after treatment with $10 \mu \mathrm{g} / \mathrm{mL}$ fraction C4 or C5 for $72 \mathrm{~h}$ (Figures 3(c) and 3(d)), indicating that fractions C4 and C5 have abilities to induce apoptosis of Bel-7404 cells. Since abnormal cell cycle is known to be responsible for initiating apoptosis under cell damage conditions, cell cycle was detected with a flow cytometer $72 \mathrm{~h}$ after treatment with $10 \mu \mathrm{g} / \mathrm{mL}$ fraction $\mathrm{C} 4$ or C5 in our study. The results demonstrated that treatment with fraction $\mathrm{C} 4$ or $\mathrm{C} 5$ resulted in the cells arrested at the $G_{0} / G_{1}$ and $G_{2} / M$ phases, suggesting that apoptosis induced by fractions $\mathrm{C} 4$ and $\mathrm{C} 5$ mainly occurs at the $G_{0} / G_{1}$ and $G_{2} / M$ phases (Figures 3(c) and 3(d)).

Apoptotic cells exhibit several biochemical modifications such as protein cross-linking, protein cleavage and DNA denaturation that ultimately lead to remarkably structural and pathological changes [17]. The alkaline comet assay is widely used for assessment of the genotoxicity of DNA damaging agents in vitro or in vivo [18]. In our study, DNA damage was detected using the alkaline comet assay after Bel7404 cells were exposed to $40 \mu \mathrm{g} / \mathrm{mL}$ fraction C4 or C5 for $72 \mathrm{~h}$. The results showed that the comets of cells treated with fraction $\mathrm{C} 4$ or $\mathrm{C} 5$ were clearly visible under the microscope. However, no comet formation was observed in untreated cells (Figure 4(a)). The percentage of tail DNA in the fractions C4 and $\mathrm{C} 5$ treated cells was significantly increased compared to the controls, indicating the genotoxic property of fractions $\mathrm{C} 4$ and C5 (Figure 4(b)).

Topoisomerases are essential nuclear enzymes that are involved in DNA supercoiling regulation and play key roles in chromosome condensation, RNA transcription, DNA replication and segregation during mitosis, and attachment of DNA loops to the chromosomal scaffold and nuclear matrix [19]. Topoisomerases has two major classes, types I and II. They are distinguished by the number of DNA strands which they cleave and the mechanism by which they alter the DNA topological properties [20]. Topoisomerase II catalyzes an ATP-dependent reaction in which one DNA double helix is supercoiled through another [21]. Disruption of the enzymatic activity of topoisomerases II induces double-strand breaks (DSBs), triggering the DNA damage response (DDR) and subsequently causing apoptosis [22]. In our present study, it was found that fractions C4 and C5 could strongly inhibit the relaxation activity of topoisomerase II in a dosedependent manner (Figures 4(c) and 4(d)), suggesting that inhibition of topoisomerases II relaxation activity may be one of the mechanisms of fraction C4- or C5-induced apoptosis. It is essential to elucidate further mechanisms of the inhibiting effect of the tested fractions on topoisomerase II activity and identify the role of the studied fractions in topoisomerase I activity in the future, since topoisomerase I is also considered as a DNA manipulating enzymes responsible for the breakage of one strand DNA [20]. 


\section{Conclusion}

Our results indicate that fractions $\mathrm{C} 4$ and $\mathrm{C} 5$ extracted from the n-butanol part of $\mathrm{CN}$ flowers showed significant cytotoxic potential towards a wide range of human malignant cell lines with low cytotoxicity to immunocytes and exhibited strong antitumor activities against Bel-7404 cells. These antitumor activities include attenuation of cancer cell proliferation as well as induction of apoptosis at the $G_{0} / G_{1}$ and $G_{2} / M$ phases through enhancement of DNA damage and inhibition of topoisomerase II relaxation activity. The pronounced antitumor actions and low immune toxicity of fractions $\mathrm{C} 4$ and C5 suggest that further studies are strongly needed to identify the chemical structures of the active compounds in these fractions and elucidate the antitumor activities of these compounds for their possible use as antitumor agents.

\section{Competing Interests}

The authors declare that there are no competing interests.

\section{Authors' Contributions}

Deng-Pan Wu, Tian-Yu Lin, and Jin-Yan Lv contributed equally to this project.

\section{Acknowledgments}

This project was supported by the Natural Science Foundation of China (nos. 81460598 and 81402946), Initializing Fund of Xuzhou Medical University, China (nos. D2014017 and D2014010), and the Natural Science Research grant of Higher Education of Jiangsu Province, China (no. 14KJD310002).

\section{References}

[1] G. B. D. Mortality, "Causes of Death C: Global, regional, and national age-sex specific all-cause and cause-specific mortality for 240 causes of death, 1990-2013: a systematic analysis for the Global Burden of Disease Study 2013," The Lancet, vol. 385, pp. 117-171, 2015.

[2] R. Siegel, J. Ma, Z. Zou, and A. Jemal, "Cancer statistics, 2014," CA Cancer Journal for Clinicians, vol. 64, no. 1, pp. 9-29, 2014.

[3] Institute of Zoology of Chinese Academy of Sciences, Illustrated Handbook of Chinese Advanced Plant, Science Press, Beijing, China, 1st edition, 1983.

[4] J. Zeng, Z. H. Huang, L. D. Li, L. Zhou, and Q. Zhou, "The abirritation effects of n-butanol extracts from cestrum nocturnum," Journal of Gannan Medical College, vol. 23, pp. 475-477, 2003.

[5] J. Zeng, F. Z. Li, H. Y. Ye, Y. S. Huang, X. H. Huang, and F. Lai, "The central inhibition effects of n-butanol extracts from cestrum nocturnum," Journal of Gannan Medical College, vol. 23, pp. 237-239, 2003.

[6] A. Kamboj, S. Kumar, and V. Kumar, "Evaluation of antidiabetic activity of hydroalcoholic extract of cestrum nocturnum leaves in streptozotocin-induced diabetic rats," Advances in Pharmacological Sciences, vol. 2013, Article ID 150401, 4 pages, 2013.

[7] H. M. Lu, Z. G. Zhong, S. Y. Zhao, and J. Y. Lv, "Antitumor activity of the extracts from cestrum nocturnum flowers,"
Lishizhen Medicine and Materia Medica Research, vol. 21, pp. 1704-1705, 2010.

[8] N. P. Singh, "The comet assay: reflections on its development, evolution and applications," Mutation Research - Reviews in Mutation Research, vol. 767, pp. 23-30, 2016.

[9] J. Janočková, J. Plšíková, J. Kašpárková et al., "Inhibition of DNA topoisomerases I and II and growth inhibition of HL-60 cells by novel acridine-based compounds," European Journal of Pharmaceutical Sciences, vol. 76, pp. 192-202, 2015.

[10] A. C. Ketron, W. A. Denny, D. E. Graves, and N. Osheroff, "Amsacrine as a topoisomerase II poison: importance of drugDNA interactions," Biochemistry, vol. 51, no. 8, pp. 1730-1739, 2012.

[11] M. Augustyniak, M. Gladysz, and M. Dziewiecka, "The comet assay in insects-status, prospects and benefits for science," Mutation Research - Reviews in Mutation Research, vol. 767, pp. 67-76, 2016.

[12] L. Ahmad, S. Jalali, S. A. Shami, and Z. Akram, "Sperm preparation: DNA damage by comet assay in normo- and teratozoospermics," Archives of Andrology, vol. 53, no. 6, pp. 325-338, 2007.

[13] L. Baranello, F. Kouzine, and D. Levens, "DNA topoisomerases: beyond the standard role," Transcription, vol. 4, no. 5, pp. 232237, 2013.

[14] I. Podolak, A. Galanty, and D. Sobolewska, "Saponins as cytotoxic agents: a review," Phytochemistry Reviews, vol. 9, no. 3, pp. 425-474, 2010.

[15] S. Arora and S. Tandon, "Achyranthes aspera root extracts induce human colon cancer cell (COLO-205) death by triggering the mitochondrial apoptosis pathway and S phase cell cycle arrest," Scientific World Journal, vol. 2014, Article ID 129697, 15 pages, 2014.

[16] L. Ouyang, Z. Shi, S. Zhao et al., "Programmed cell death pathways in cancer: a review of apoptosis, autophagy and programmed necrosis," Cell Proliferation, vol. 45, no. 6, pp. 487498, 2012.

[17] W. P. Roos and B. Kaina, "DNA damage-induced cell death: from specific DNA lesions to the DNA damage response and apoptosis," Cancer Letters, vol. 332, no. 2, pp. 237-248, 2013.

[18] A. R. Collins, "Measuring oxidative damage to DNA and its repair with the comet assay," Biochimica et Biophysica ActaGeneral Subjects, vol. 1840, no. 2, pp. 794-800, 2014.

[19] S. Sobek and F. Boege, "DNA topoisomerases in mtDNA maintenance and ageing," Experimental Gerontology, vol. 56, pp. 135-141, 2014.

[20] S. H. Chen, N.-L. Chan, and T.-S. Hsieh, "New mechanistic and functional insights into DNA topoisomerases," Annual Review of Biochemistry, vol. 82, pp. 139-170, 2013.

[21] A. D. Bates, J. M. Berger, and A. Maxwell, “The ancestral role of ATP hydrolysis in type II topoisomerases: prevention of DNA double-strand breaks," Nucleic Acids Research, vol. 39, no. 15, pp. 6327-6339, 2011.

[22] C.-C. Chang, Y.-R. Wang, S.-F. Chen, C.-C. Wu, and N.-L. Chan, "New insights into DNA-binding by type IIA topoisomerases," Current Opinion in Structural Biology, vol. 23, no. 1, pp. 125-133, 2013. 


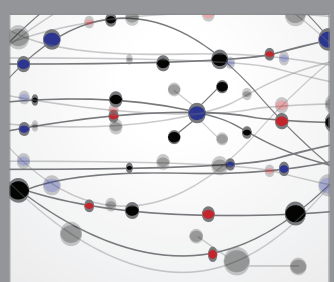

The Scientific World Journal
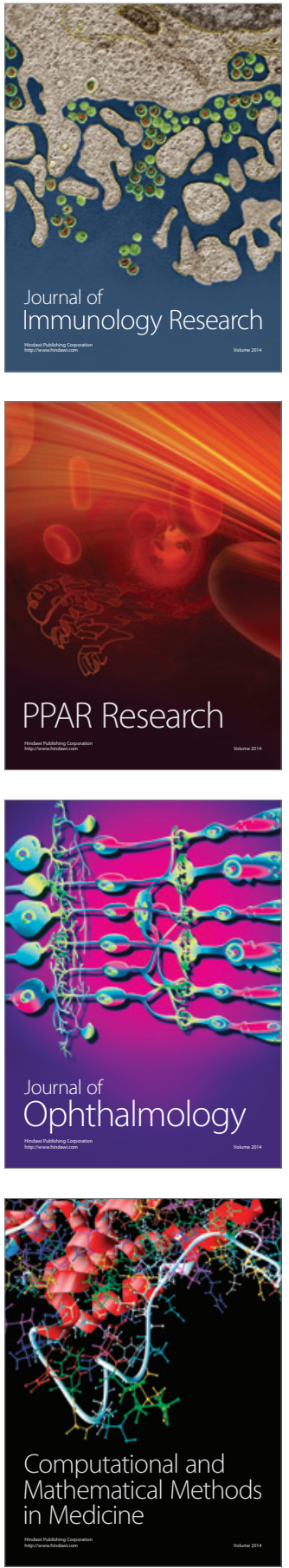

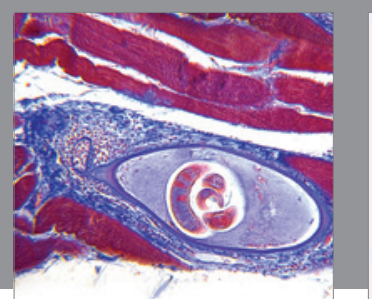

Gastroenterology Research and Practice
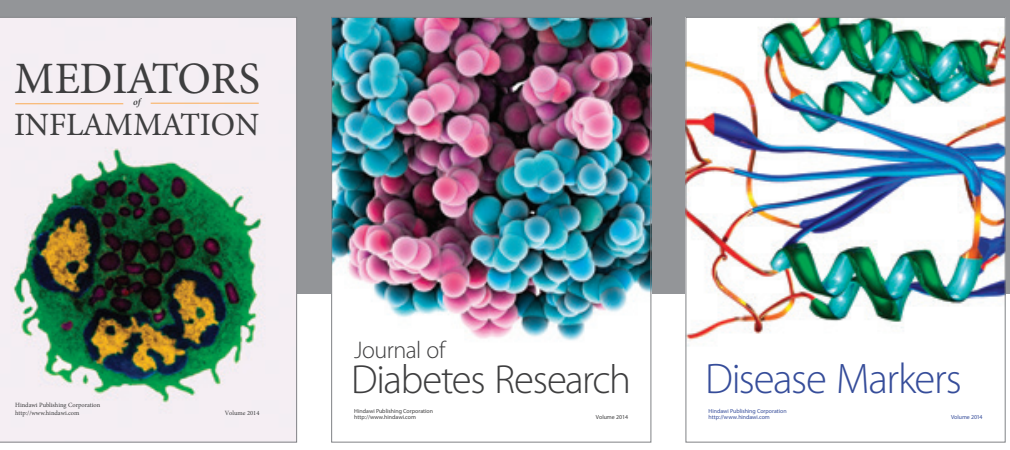

Disease Markers

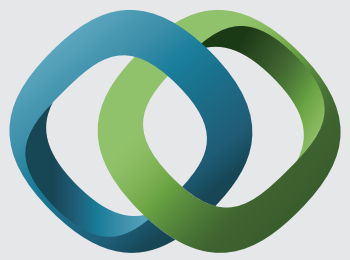

\section{Hindawi}

Submit your manuscripts at

https://www.hindawi.com
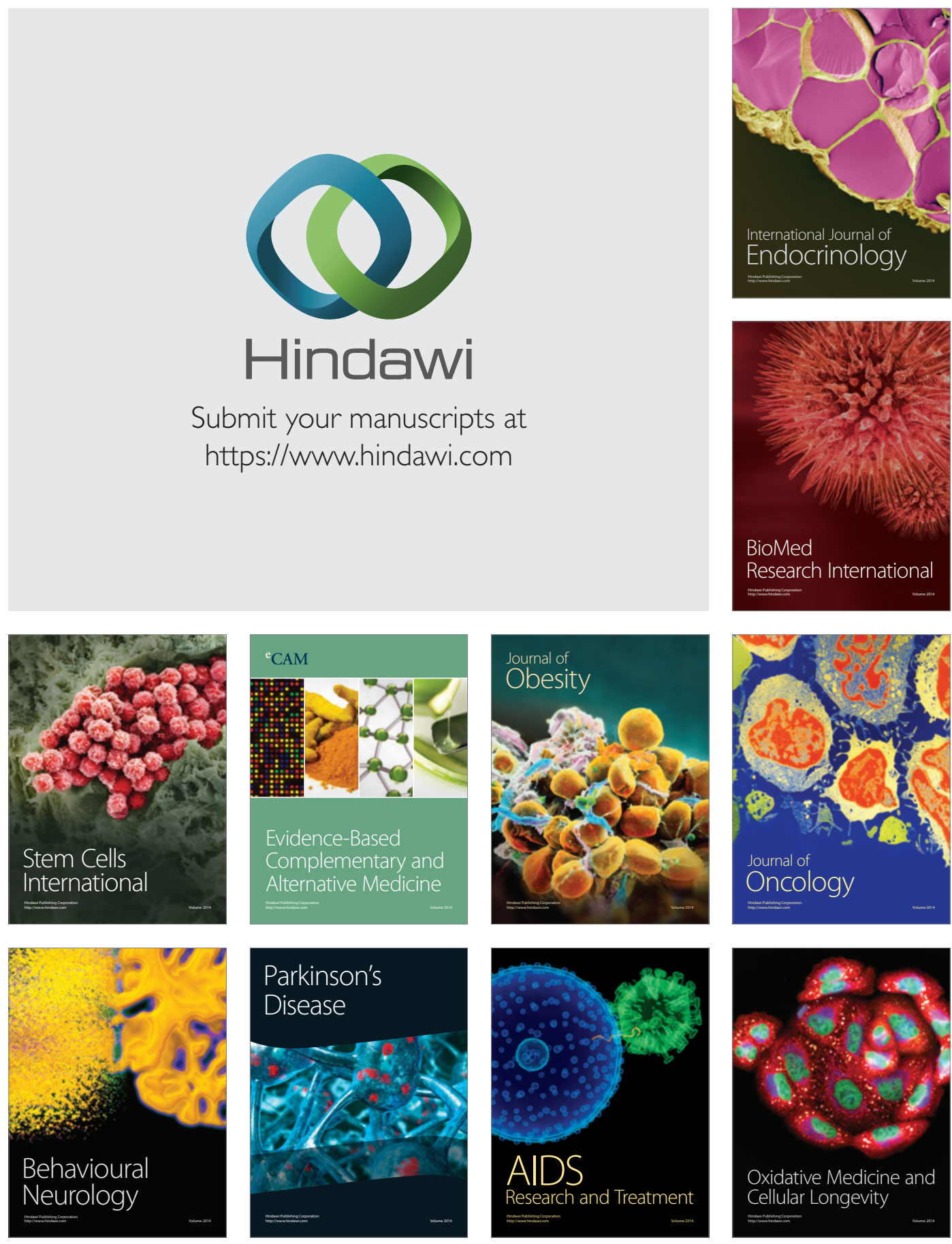